\title{
OCEANOGRAPHIC ASPECTS OF THE RECRUITMENT OF EELS TO THE BALTIC SEA.
}

\author{
HÅKAN WESTERBERG
}

\author{
National Board of Fisheries, Institute of Coastal Research, Nya Varvet 31, \\ S-42671 Västra Frölunda, Sweden.
}

\begin{abstract}
The processes by which eels arrive to the Baltic Sea are discussed in the light of an almost total lack of $0+$ eels in the Kattegatt and the Sound during 1996. The comparatively high elver abundance at the Skagerrak coast the same year indicates that this was due to a failure of the glass eels to penetrate into the Kattegatt, which can be attributed to a lack of westerly winds during the winter and early spring. A tentative scenario is a mainly passive surface advection south along the Swedish Kattegatt coast followed by an active migration of the 0+ elvers in a narrow, shallow coastal region through the Sound and into the Baltic.
\end{abstract}

\section{ASPECTS OCÉANOGRAPHIQUES DU RECRUTEMENT EN ANGUILLES DANS LA BALTIQUE.}

\section{RÉSUMÉ}

Les processus de colonisation de la Baltique par les anguilles sont discutés en se basant sur la quasi absence d'individus 0+ dans le Kattegatt et le Sound en 1996. La même année, l'abondance des civelles était comparativement plus élevée sur la côte de Skagerrak, ce qui indique que les anguilles n'ont pas pu pénétrer dans le Kattegatt. Ceci pourrait être dû à l'absence de vent d'ouest durant l'hiver et le début du printemps. Le scénario suivant peut être avancé : une migration passive des civelles due au courant d'advection vers le sud, le long de la côte suédoise du Kattegatt, serait suivie d'une migration active d'anguillettes 0+ dans la région côtière du Sound jusque dans la Baltique.

\section{BACKGROUND}

The eel fishery in the Baltic area is of great importance, with an annual catch which used to be 8,000 tons/year before the recruitment decline during the last decades (sum of the fishery in the sea and in the drainage area compiled from TESCH, 1977) and which now can be estimated to 3,000 tons/year. Hydrographically the Baltic Sea, the Danish Belts and Kattegatt act as a gigantic estuary, where the Baltic in many ways resembles a lake, 
whereas the Belt Sea and Kattegatt have river-like properties, connecting the Baltic lake to the extension of the North Sea which is called Skagerrak. Surface water in the Baltic has a residence time of about 25 years and will make maybe a hundred revolutions within the basin before it leaves through the Danish Belts or the Sound. In the shallow Kattegatt the Baltic water passes in just one or two months from the south to the north, where it arrives at a salinity front called the Skagerrak front. This front follows the $100 \mathrm{~m}$ isobath from Skagen to the Swedish west coast (Figure 1). Here the Kattegatt surface water is compressed and continues as a coastal current north and west out of the Skagerrak. North Sea water, both from the southern and northern North Sea, combines in the Jutland current which enters Skagerrak from south-west and follows the Skagerrak front before turning in an anticlockwise loop through Skagerrak. A part of the Jutland current dives under the Kattegatt surface water and forms a south-moving deepwater current in the Kattegatt. This deepwater is continuously mixed up into the brackish Baltic water from the south, which causes a north-south salinity gradient from approximately 30 to $10 \%$ in the Kattegatt surface water.

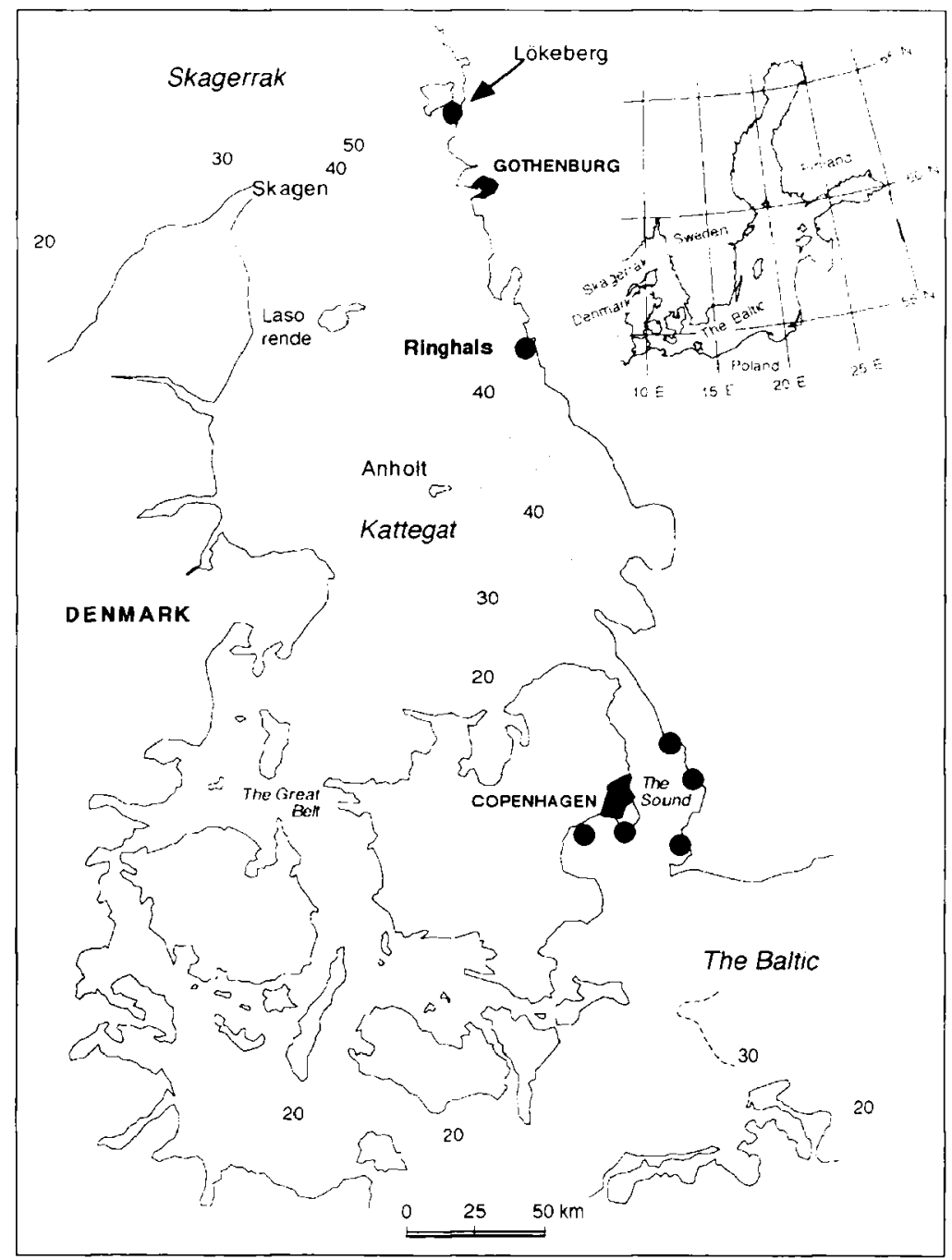

Figure 1

Bathymetric chart of the Kattegatt and the Belt Sea. The elver sampling places are marked with dots. The insert shows an overview of the Baltic region.

\section{Figure 1}

Enregistrement bathymétrique dans le Kattegatt et dans la mer Belt. Les lieux des prélèvements sont indiqués par des points. Une vue générale de la région baltique est présentée. 
The flow over the sills of the Danish straits is essentially barotropic, i.e. with the same direction and salinity at all depths. The exchange of salt to the Baltic occurs in periods when wind and sea-level conditions reverse the flow and salty Kattegatt water is forced south, alternating with periods of Baltic surface water outflow. The instantaneous inflows and outflows are of an order of magnitude larger than the mean flow and carry salinities between 8 and $28 \%$.

\section{THE RECRUITMENT TO THE BALTIC}

Glass eels from the North Sea arrive in the Jutland current in January or February. This is during the time of the year when the inflows of salt water to the Baltic Sea are most intense and frequent. A plausible mechanism for the transport of eels to the Baltic could be by an advection with the southgoing Kattegatt surface or deepwater during such events. In this case, one should expect an increase of small eels in the Baltic subsequent to major winter inflows. Such inflows are relatively rare but tend to come in clusters during two or three years in succession. There are also long periods without major inflow events, as for example 1983 to 1992. The occurrences of inflows have been reviewed by MATTHÄUS (1993). Comparing his data to the available records of ascending small yellow eels in three Baltic rivers, it is difficult to find evidence for a connection (Figure 2). An example is that the intense inflow period 1969 to 1972 leaves hardly any trace in the abundance of small eels.

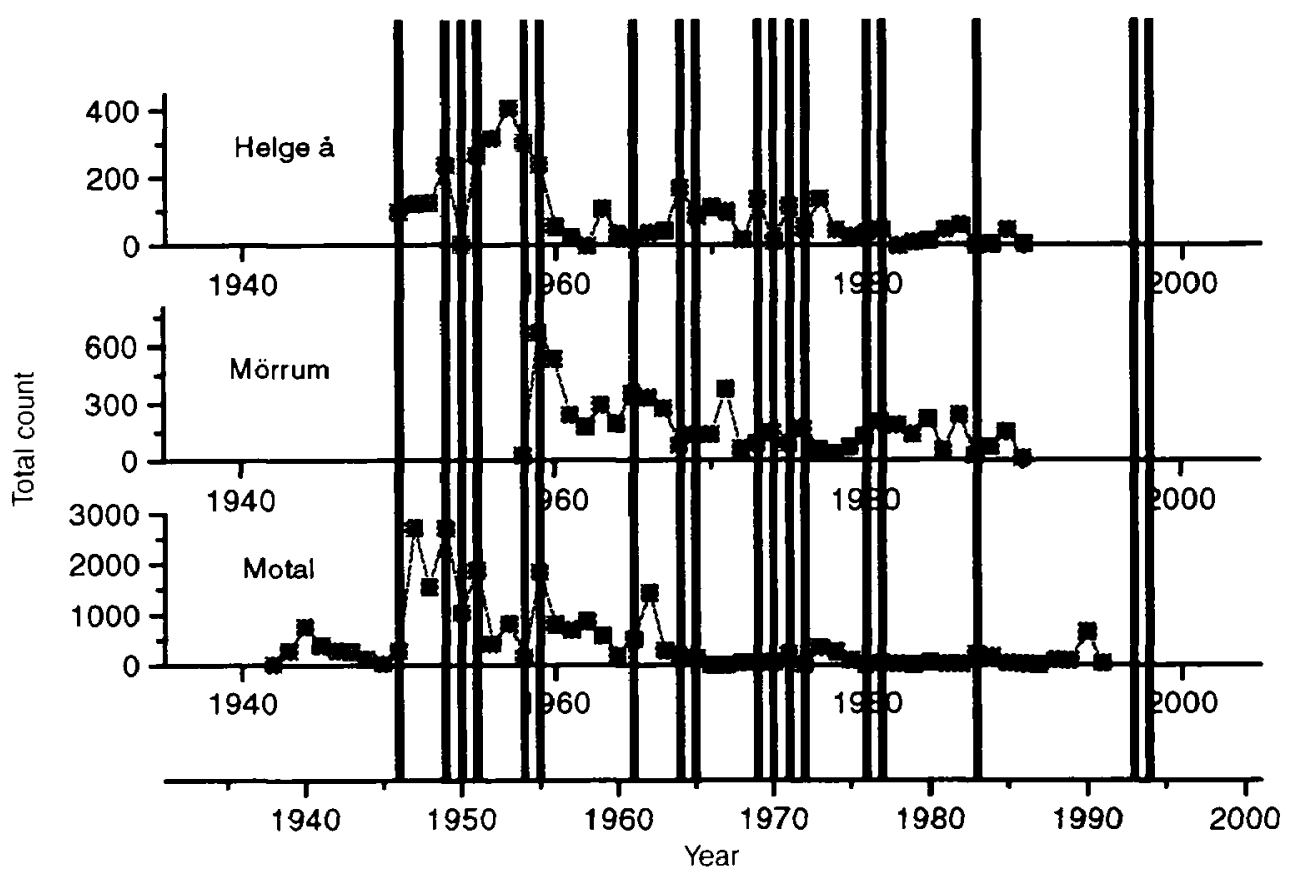

Figure 2

The yearly catch of small yellow eels at three collectors placed in rivers discharging in the Baltic proper. The bars show years with one or several major inflows to the Baltic (data from MATTHÄUS, 1993). The inflow diagram has been offset 4 years, corresponding to the most probable age of the ascending yellow eels.

Figure 2

Capture annuelle de petites anguilles jaunes dans trois collecteurs placés dans des rivières débouchant dans la mer Baltique. Les barres indiquent les années de débits importants vers la Baltique (d'après MATTHÄUS, 1993). Le diagramme a été décalé de 4 ans pour tenir compte de l'âge probable des anguilles jaunes qui remontent. 
If the eels do not advect to the Baltic during the glass eel stage, the alternative is an active migration as elvers. An indication that this may be the case is the very high abundance of 0 + elvers found along the Swedish side of the Sound (WESTERBERG et al., 1993). Samplings in July each year since 1992 have shown an eel density of $1-2 \mathrm{eels} / \mathrm{m}^{2}$, or in total about 50 million elvers in the Sound area. Of those approximately $80 \%$ are $0+$, implying a large emigration of this year class between years; presumably to the Baltic. There is a marked asymmetry with a much lower, approximately $1 / 10$, abundance on the Danish side, which fits with the hypothesis that the elvers arrive from settling places along the shoreline northwards.

\section{THE SPECIAL CONDITIONS IN 1996}

As is seen in Table 1, the conditions were rather stable from 1992 to 1995 and then the abundance of 0+ elvers dropped dramatically in 1996.

\section{Table 1}

Mean abundance of $0+$ elvers measured with drop-trap in the 0.5 to $1.5 \mathrm{~m}$ depth interval at five places in the Sound.

\section{Table 1}

Quantité moyenne d'anguillettes $0+$ mesurée, à l'aide d'un piège à gouttes, à des intervalles de profondeur de 0,5 à $1,5 \mathrm{~m}$, à cinq endroits dans le Sound.

\begin{tabular}{ccc} 
Year & Swedish side & Danish side \\
& \multicolumn{2}{c}{$\left(\right.$ eels $\left./ \mathrm{m}^{2}\right)$} \\
1992 & 0.65 & no data \\
1993 & 1.19 & 0.16 \\
1994 & 1.41 & 0.37 \\
1995 & 0.84 & 0.10 \\
1996 & 0.07 & 0.03 \\
\hline
\end{tabular}

As the eel monitoring in the Sound is part of the environmental investigations connected to the dredging operations for the Öresund Fixed Link, it was of great interest to check whether this was a local phenomenon in the Sound or a regional event. To this end the recruitment at other points along the Swedish west coast has been studied. One set of data was the glass eel sampling which made in the cooling water intake to the Ringhals nuclear power plant. During the glass eel season, from late January through April, an Isaac Kidd Midwater Trawl (IKMT) was placed in the 2 knots flow of the intake channel during 2-4 nights each week. This gave an integrated index of the glass eel concentration in the middle part of the Kattegatt. Figure 3 shows how this index was related to the mean $0+$ abundance on the Swedish side of the Sound. The correlation was very good during the 5 years of measurements and the year 1996 was evidently a very poor year in the Kattegatt also.

Further north, in Lökeberg, about $50 \mathrm{~km}$ north of Gothenburg and near the landfall of the Skagerrak front the elver abundance has been measured using drop-traps in 1985 and 1986 (WESTERBERG, 1987). At that time the abundance was $0.09 \mathrm{eel} / \mathrm{m}^{2}$ for $0+$ elvers. In 1996, the abundance increased to $0.32 \mathrm{eel} / \mathrm{m}^{2}$. In 1986, the Ringhals index was about 3 times higher than in 1996, so this means that the observed abundance at Lökeberg in 1996 is about 10 times higher than what should be expected had the abundances been determined by a common external factor. The conclusion is that the Skagerrak and the Kattegatt probably have independent glass eel transport mechanisms. 


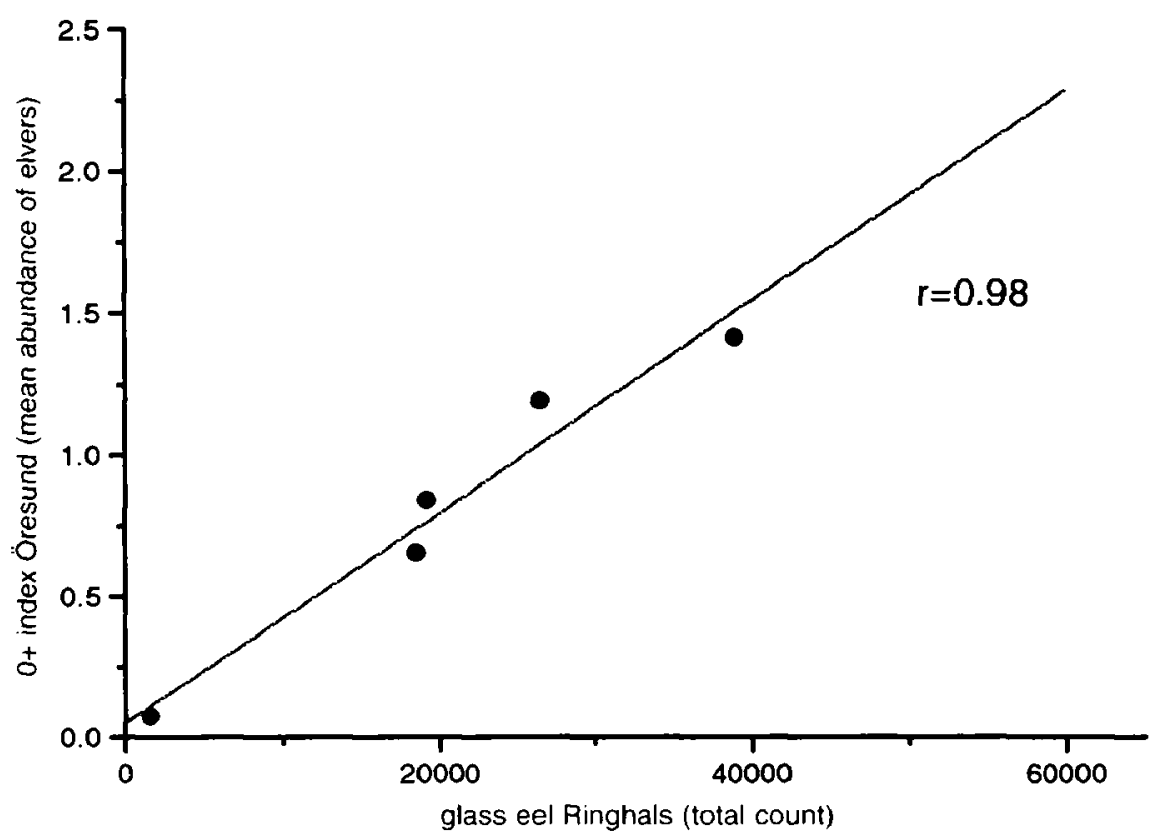

Figure 3

Relation between the time integrated glass eel concentration at Ringhals and the mean $0+$ elver abundance in the 0.5 to $1.5 \mathrm{~m}$ depth interval on the Swedish side of the Sound 1992-1996. The $0+$ index is the mean abundance of elvers over the three sampling sites occupied on the Swedish side of the Sound, where elvers means small yellow eels that have arrived as glass eels the same year. The $0+$ year class is defined conventionally according to the date of metamorphosis to glass eels.

\section{Figure 3}

Relation entre la concentration des civelles au Ringhals, intégrée sur le temps, et le niveau moyen de civelles $0+$ mesuré à des intervalles de profondeur de 0,5 à $1,5 \mathrm{~m}$ sur la rive suédoise du Sound, de 1992 à 1996 . L'indice 0+ est l'abondance moyenne des anguillettes échantillonnées sur les trois sites de la rive suédoise du Sound. Le terme anguillette fait référence aux petites anguilles jaunes qui sont arrivées comme civelles la même année. La classe d'âge $0+$ est définie par convention à partir de la date de métamorphose en civelles.

We can now look at a third time series of glass eel measurements. Since 1975 glass eels have been monitored using IKMT east of $8^{\circ} \mathrm{E}$ in the Skagerrak and the Kattegatt during the Young Fish Survey (YFS) in February (HAGSTRÖM and WICKSTRÖM, 1989). The IKMT was replaced by a MIK-trawl from 1992 onwards. The early IKTM-part of the time series correlates fairly well with the catches at Ringhals (Figure 4). Looking at the MIK results during the last few years, it is seen that the 1996 catch was the lowest ever : just $10-20 \%$ of that during the preceding years.

This seems to indicate that the cause for the low glass eel abundance in 1996 lies in the supply from the North Sea. This is however contradicted by the high elver concentration found in Bohuslän. Looking at the distribution of the YFS catches (Figure 5) another explanation seems more likely. In 1996 the few glass eels caught were all found in the extreme western part of the survey area, whereas in earlier years the glass eels were distributed in the eastern Skagerrak and the Kattegatt. This means that the progress of the glass eels in the North Sea could have been delayed and that a later survey might have shown a more normal glass eel invasion. 


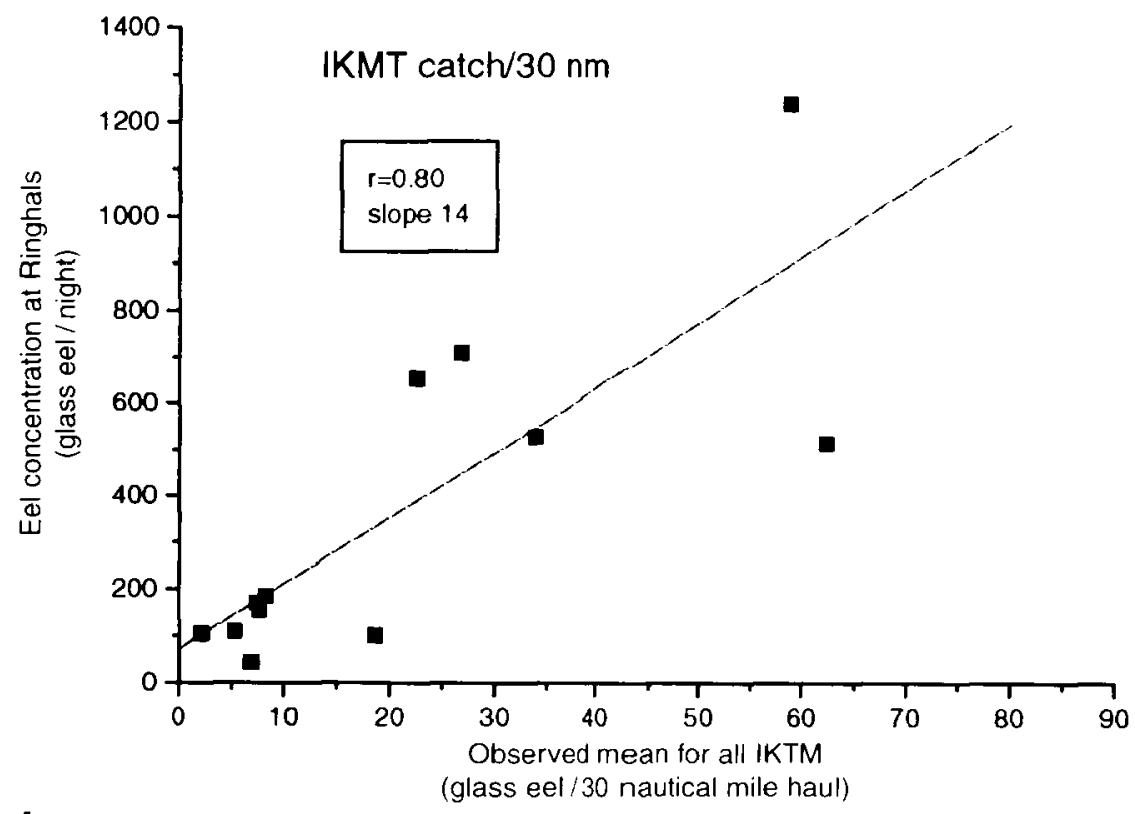

Figure 4

(glass eel/30 nautical mile haul)

Relation between the mean glass eel concentration at Ringhals and the observed mean for all IKTM (Isaak Kidd Midwater Trawl) hauls during the YFS (Young Fish Survey) from 1978 to 1989.

\section{Figure 4}

Relation entre la concentration des civelles au Ringhals et la moyenne observée pour toutes les pêches d'IKTM pendant l'étude sur les jeunes poissons de 1978 à 1989.

\section{TRANSPORT MECHANISM IN THE KATTEGATT}

What then was the cause of the low Kattegatt recruitment in 1996 ? If we assume a local explanation, the hydrography of the area can give a clue. The surface currents of the Kattegatt can be separated into three parts : a mean, northwards estuarine flow $(5-10 \mathrm{~cm} / \mathrm{s})$, more intense in the winter season (ANDERSSON and RYDBERG, 1993). Superposed on this steady motion, there are larger fluctuations forced by the wind and water level changes. Those irregular currents have a mean velocity magnitude of around $25 \mathrm{~cm} / \mathrm{s}$ (SVANSSON, 1975). Finally, there are weak tidal currents, with a semi-diurnal amplitude of approximately $10 \mathrm{~cm} / \mathrm{s}$ (BIELER and SVANSSON, 1977).

The meteorologically forced currents is the component which dominates at any given moment. The relation between the surface current direction and the wind was analysed by DIETRICH (1951). In the northern half of the Kattegatt he found predominantly northgoing currents at all wind directions except from the west, in which case there is a southward going current along the Swedish coast. The relatively high prevalence for westerly winds at this latitude means that on average the surface currents indeed are directed to the south in a less than $10 \mathrm{~km}$ broad region along the coast, with velocities of approximately $2 \mathrm{~cm} / \mathrm{s}$ (ANDERSSON and RYDBERG, 1993). If this weak flow did not exist, the glass eels would be swept out of the Kattegatt by the combined estuarine and wind-driven currents because of their passive swimming behaviour. A tidal transport does not seem very likely. Because of the small depths, there is a 5 hours tide phase delay between northern and southern end of the Kattegatt. Moreover, since the random meteorological fluctuations have a larger amplitude than tidal currents, local tide currents are not necessarily related to general ocean tidal rhythmes. 


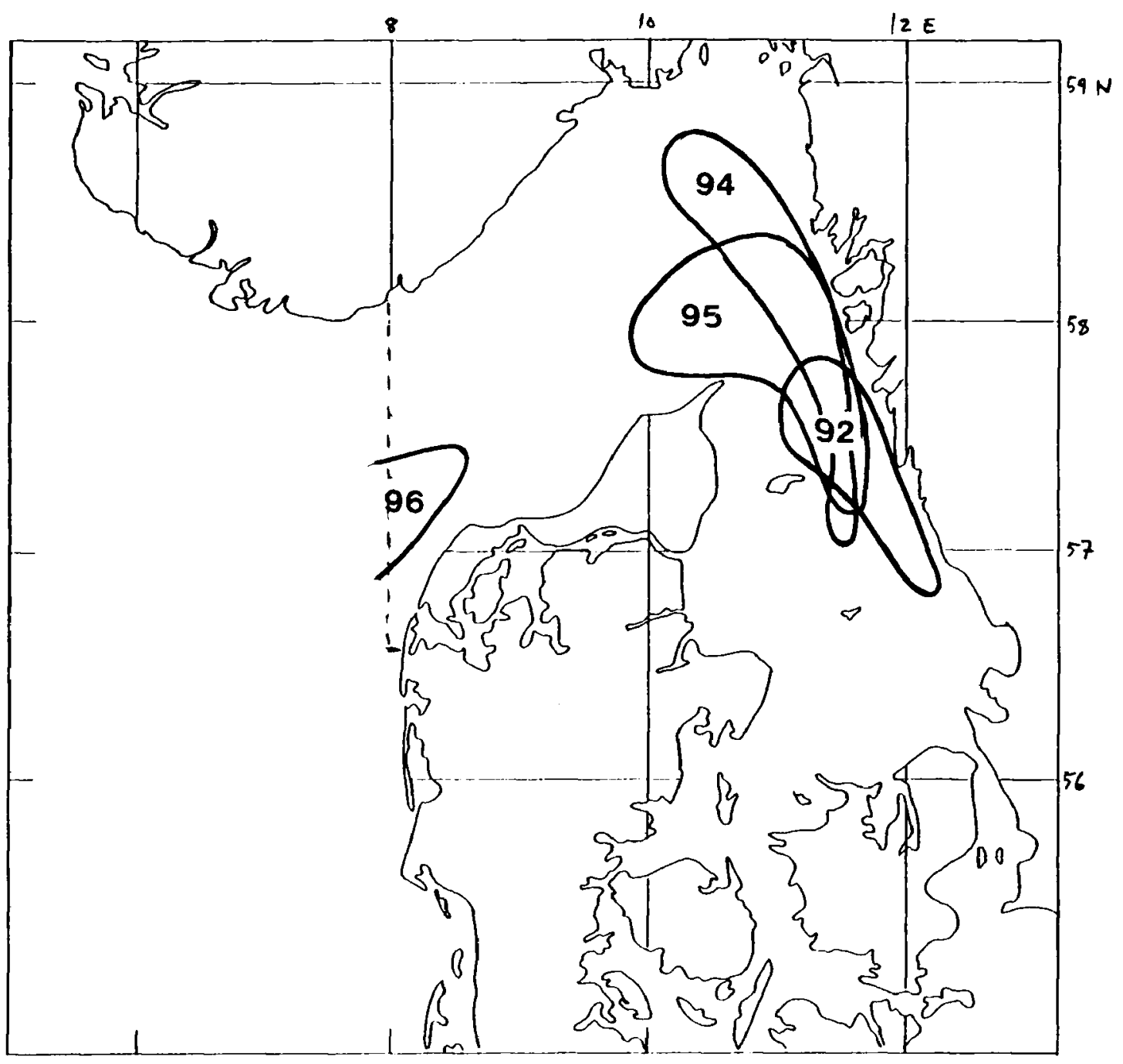

Figure 5

Central distribution of glass eels in February as found during four recent years of the Young Fish Survey.

\section{Figure 5}

Distribution centrale des civelles au mois de février durant les 4 dernières années de l'YFS (étude sur les jeunes poissons).

With this in mind, the wind conditions over Kattegatt during the glass eel season at Ringhals was compared to the observed yearly catch. The first glass eels arrive at Ringhals in the late January or early February, about at the same time as the center of the Skagerrak glass eel distribution is east of Skagen. The bulk of the catch is however made in March and April. The distance from Ringhals to the Skagerrak front is approximately $100 \mathrm{~km}$, so a delay of one or two months fits with a mean southerly advection of $2 \mathrm{~cm} / \mathrm{s}$. The length axis of the Kattegatt is approximately NW to SE. The transport of the surface water due to the action of the wind, the Ekman transport, is ideally perpendicular to the right of the wind direction and proportional to the windstress. As a measure of the effects of the wind the ratio of monthly mean NE component to the mean SW component of the windstress was used. A high value means that conditions where the Ekman transport is out of the Kattegatt dominates. The normal climatic situation with predominantly westerly winds gives a low value for the windstress ratio. Figure 6 shows how the catch varies in relation to this ratio. It can be seen 
that the two isolated years with the highest ratio are 1980 and 1996 and that, in both cases, there is a sudden drop in the glass eel catch. The period 1984 to 1988 is low in glass eel abundance and shows a mostly higher than average windstress ratio. Those observations are at least suggestive of a connection between sparse westerly winds and a failure of the glass eel to penetrate into the Kattegatt.
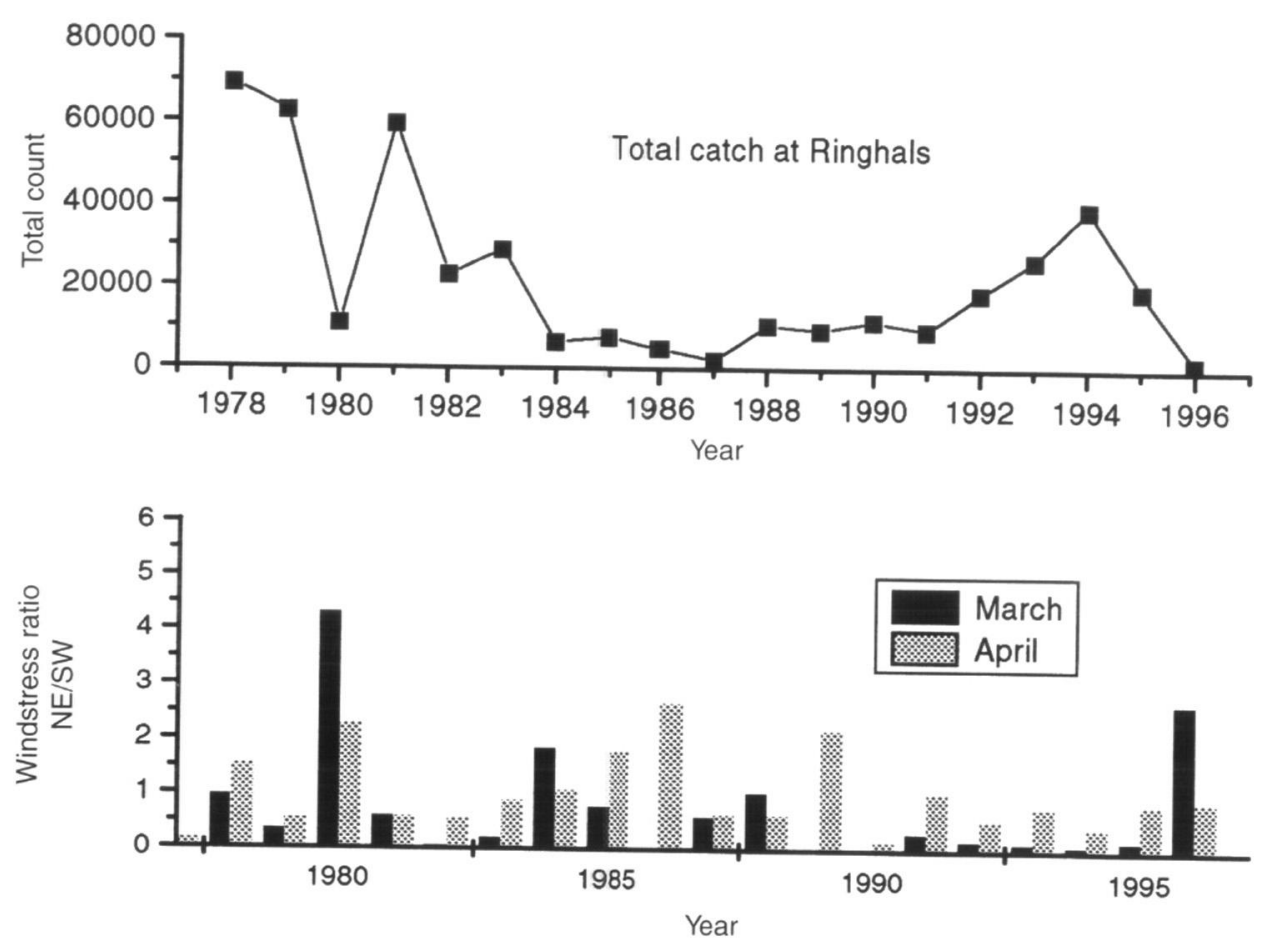

Figure 6

Integrated glass eel concentration observed at Ringhals and monthly mean ratio of the NE and SW components of the windstress. Wind observations are from the meteorological station at Måseskär.

\section{Figure 6}

Concentration intégrée des civelles observée au Ringhals et rapport moyen mensuel des composantes nord-est et sud-est du vent. Les observations sur le vent proviennent de la station météorologique de Måseskär.

The picture of the way in which glass eels arrive to the Baltic that emerges from this examination of the absence of 0+ elvers in 1996 is the following : the eels arrive via the Jutland current in January-February and impinge on the Swedish Skagerrak coast. Some might be advected south in the deepwater flow in the central Kattegatt. If, however, they rise to the surface layer they will in the mean be flushed out of the Kattegatt again. Mixing along the Skagerrak front will spread eels into the Kattegatt surface water and an advection will take place very slowly southwards along the eastern side of the Kattegatt. This advection is blocked during years with a lack of westerly winds leading to a recruitment failure south of the Skagerrak front. Subsequently the eels will settle as elvers in a narrow coastal zone and then continue into the Baltic by active migration in a shallow zone close to the beach. This scenario is evidently very uncertain, but it may serve as a working model for the future study of the recruitment process. 


\section{ACKNOWLEDGEMENTS}

This study was funded by the Öresundskonsortium. Henrik SVEDÄNG has been of help in compiling data and discussion of the results. Håkan WICKSTRÖM and Johan MODIN supplied the YFS data and Bo GUSTAVSSON made the windstress calculations.

\section{REFERENCES}

ANDERSSON L., RYDBERG. L., 1993. Exchange of water and nutrients between the Skagerrak and the Kattegatt estuarine. Coastal and Shelf Science, 36, 159-181.

BIELER H., SVANSSON. A., 1977. Tidal and spectral analysis of Kattegatt time series of current and salinity. Medd. Havsfiskelb. Lysekil., No 209, 7 p.

DIETRICH G., 1951. Oberflächenströmungen im Kattegat, im Sund, und in der Beltsee. Deut. Hydrogr. Z., 4, 129-150.

HAGSTRÖM O., WICKSTRÖM H., 1989. Immigration of glass eels to the Skagerrak-Kattegatt area. EIFAC Working Party on eels, Porto 1989, 9 p.

MATTHÄUS W., 1993. Major inflows of highly saline water into the Baltic sea - a review. ICES C.M.1993/C:52, $10 \mathrm{p}$.

SVANSSON A., 1975. Physical and chemical oceanography of the Skagerrak and the Kattegatt. I - Open sea conditions. Report, Fish. Bd. Sweden, Inst. Mar. Res., No 1, $88 \mathrm{p}$.

TESCH F.W., 1977. The eel. Chapman \& Hall, London, $434 p$.

WESTERBERG H., 1987. Utsättning av ål på Västkusten, del 3. Yrkesfiskaren, 19-87, 8-9.

WESTERBERG H., HAAMER J., LAGENFELT. I., 1993. A new method for sampling elvers in the coastal zone. ICES C.M.1993/M:5, $10 \mathrm{p}$. 